Crop Breeding and Applied Biotechnology 15: 94-99, 2015

Brazilian Society of Plant Breeding. Printed in Brazil

\title{
ARTICLE
}

http://dx.doi.org/10.1590/1984-70332015v15n2a17

\section{An efficient shoot regeneration system for medicinally important Elephantopus scaber Linn.}

\author{
Jyothi Abraham ${ }^{1,2}$ and T. Dennis Thomas ${ }^{2}$
}

Received 22 October 2014

Accepted 6 January 2015

\begin{abstract}
An efficient protocol for the rapid micropropagation of medicinally important Elephantopus scaber has been standardized using cotyledonary node explants. Direct multiple shoot induction was observed when the cotyledonary node explants at various age groups were cultured on MS medium supplemented with various plant growth regulators. The highest shoot induction was obtained when the cotyledonary node explants from 20-day-old seedlings were cultured on MS medium supplemented with $1.5 \mathrm{mg} \mathrm{L} \mathrm{L}^{-1} \mathrm{TDZ}$ and $0.5 \mathrm{mg} L^{-1} \mathrm{NAA}$. On this medium, 98\% of the cultures responded, with an average number of 33.7 shoots per explant. The highest frequency of rooting (100\%) and mean number of roots (3.3 per shoot) were observed when the shoots were transferred to MS medium supplemented with $1.0 \mathrm{mg} L^{-1} I B A$. The plantlets raised in vitro were acclimatized and transferred to soil with a $92 \%$ success rate. The protocol described here may be utilized for multiplication and conservation of elite clones of E. scaber.
\end{abstract}

Key words: Acclimatization, cotyledonary node, Elephantopus scaber, multiple shoots, rooting.

\section{INTRODUCTION}

Elephantopus scaber L., popularly known as “Elephant's foot", is a valuable medicinal herb belonging to the family Asteraceae. It is distributed in the tropical regions of Southeast Asia and Latin America (Cabrera and Klein 1980). The plant is characterized by a forked, stiff stem, with a purple inflorescence (flower head). E. scaber has been used in traditional medicine to treat various diseases in several countries (for a review see Hiradev and Rangari 2014). It is used against cardiovascular diseases, bronchitis, and smallpox (Kiritikar and Basu 1991). The healing properties of the roots of this plant are useful for heart and liver problems, and a hot water extract of the roots is used in combating filariasis and diarrhea (Hammer and Johns 1993). The fresh roots are used in the treatment of leucorrhoea, metrorrhagia, menorrhagia, and dysmenorrhea (Behera and Misra 2005). The root part is used to cure headaches, a leaf paste to treat menorrhagia and paste from the entire plant applied externally to cure tetanus (Rajakumar and Shivanna 2010). Furthermore, the roots are used externally as an anti-venom, as an antiseptic for cuts and wounds, and on lesions for chicken pox. It is also used against dysentery, diarrhea, stomach troubles, and tuberculosis (Hammer and Johns 1993).
The medicinal properties of E. scaber are due to its phytochemical components, and several important constituents have been isolated from various parts of the plant. These important phytochemicals include deoxyelephantopin, isodeoxyelephantopin, scabertopin, elescaberin, scabertopinol, hexadecanoic acid, octadecadienoic acid, n-tetradecane, tetramethyl hexadecenol, isopropyl dimethyl tetrahydronaphthalenol, phytol, stigmasterol, tricin, lupeol, betulinic acid, and luteolin (Chang et al. 2011, Geetha et al. 2012). The compounds deoxyelephantopin and isodeoxyelephantopin isolated from $E$. scaber exhibited strong anticancer properties (Geetha et al. 2012, Lee and Shyur 2012). Destructive harvesting of this plant for medicinal purposes, lack of knowledge of proper cultivation methods, habitat destruction, and deforestation have resulted in rapid depletion of the natural stock of this plant. Its natural propagation is through seeds, but low rate of seed set, poor seed viability, and early seedling death are the major hurdles for its natural propagation (Parashurama et al. 2013).

With the advent of plant tissue culturing and associated biotechniques, supplementary conservation strategies have now been employed for protecting valuable germplasms. In vitro propagation, an ex situ conservation strategy, contrib-

\footnotetext{
${ }^{1}$ Research and development center, Bharathiar University, Maruthamalai Road, Coimbatore, Tamil Nadu PIN-641046, India

${ }^{2}$ Postgraduate and Research Department of Botany, St. Thomas College, Palai, Arunapuram (P.O), Kottayam, Kerala 686 574, India.*E-Mail: den_thuruthiyil@yahoo. com
} 
utes to new means for conservation and mass propagation of economically important plants. In addition, in vitro plant systems, combined with other complementary strategies, serve as an alternative approach for effective and sustainable conservation. In vitro micropropagation for commercial production and ex situ conservation has been successfully applied to various plant species (Rodrigues et al. 2015, Cheruvathur et al. 2013, Cheruvathur and Thomas 2014). In vitro propagation and conservation of several Asteraceae species, including endangered and threatened medicinal plants, have been reported. These species include Eclipta alba (Baskaran and Jayabalan 2005) and Crepis novoana (Corral et al. 2011). There are some preliminary studies on micropropagation of E. scaber using seed- and leaf-derived callus organogenesis (Jagadeesh Singh et al. 2004, Rout and Sahoo 2013). However, direct shoot regeneration in $E$. scaber has not been reported. The aim of the present study was to establish a rapid in vitro regeneration system through multiple shoot induction using cotyledonary node explants. This study is useful because it provides a reliable source of E. scaber plants to replenish declining populations in the wild and to be used for biocompound extraction, reducing pressure on wild stocks.

\section{MATERIAL AND METHODS}

\section{Plant material and culture medium}

The mature seeds of E. scaber were collected from field grown plants and surface sterilized with $3 \%(\mathrm{v} / \mathrm{v})$ sodium hypochlorite solution for $10 \mathrm{~min}$, followed by three rinses in autoclaved double-distilled water. The seeds were then transferred to a sterile Petri plate with sterile filter paper (Whatman no. 1) soaked with sterile MS basal medium (Murashige and Skoog 1962). The seeds (about 50-70 seeds/ Petri plate) were placed on the filter paper under aseptic conditions in a laminar air flow chamber and incubated for germination in the culture room. The cotyledonary node explants (which included 0.5-1.5 mm epicotyl and hypocotyl regions with 2 attached cotyledons), after removing the radicle, were excised from 15-, 20-, and 25-day-old seedlings maintained in vitro and cultured vertically in $25 \times 150$ $\mathrm{mm}$ test tubes containing MS medium supplemented with various concentrations of 6-benzylaminopurine (BA; 0.5$3.0 \mathrm{mg} \mathrm{L}^{-1}$ ) and thidiazuron (TDZ; 0.5-3.0 $\mathrm{mg} \mathrm{L}^{-1}$ ) alone or in combination with naphthalene acetic acid (NAA; $\left.0.3-1.0 \mathrm{mg} \mathrm{L}^{-1}\right)$.

\section{Multiple shoot induction, rooting, and transfer to soil}

The response was expressed in terms of per cent response, mean number of shoots, and mean shoot length, and data was recorded $45 \mathrm{~d}$ after culturing. Induced multiple shoots were taken out of the culture and each shoot was isolated and cultured on MS medium supplemented with $0.5 \mathrm{mg}$ $\mathrm{L}^{-1} \mathrm{BA}$ for shoot elongation. The shoots with a size greater than $2.5 \mathrm{~cm}$ from the primary culture as well as from the elongation medium were used for rooting experiments. The shoots were cultured on half-strength MS medium with the addition of different concentrations of NAA (0.5-2.0 $\left.\mathrm{mg} \mathrm{L}{ }^{-1}\right)$, IBA $\left(0.5-2.0 \mathrm{mg} \mathrm{L}^{-1}\right)$, or IAA (0.5-2.0 $\left.\mathrm{mg} \mathrm{L}^{-1}\right)$ for rooting. Percentage of shoots rooted, mean number of roots, and mean root length were recorded $45 \mathrm{~d}$ after culturing.

For hardening, the regenerated shoots with vigorous root systems were transferred to small plastic cups ( $6 \mathrm{~cm}$ diameter) containing a sterile sand:soil (1:1) mixture and placed in a greenhouse under high humidity (90\%). The plantlets were irrigated initially with sterile MS basal medium for $14 \mathrm{~d}$, followed by tap water. Initially the plants were kept under reduced light $\left(20 \mu \mathrm{mol} \mathrm{m}^{-2} \mathrm{~s}^{-1}\right)$ intensity and slowly shifted to comparatively high light intensities $\left(40 \mu \mathrm{mol} \mathrm{m}^{-2} \mathrm{~s}^{-1}\right)$. After 2 months, the plants were moved out of the greenhouse and placed in shade (approximately 60\% shade) under natural conditions. The acclimatized plants were transferred to an outdoor environment after three months.

\section{Culture conditions}

All media were supplemented with $3 \%(\mathrm{w} / \mathrm{v})$ sucrose and $0.8 \%(\mathrm{w} / \mathrm{v})$ agar, and the $\mathrm{pH}$ was adjusted to 5.8 with 1.0 $\mathrm{N} \mathrm{HCl}$ or $1.0 \mathrm{~N} \mathrm{NaOH}$. All culture media were autoclaved at $121{ }^{\circ} \mathrm{C}$ for $20 \mathrm{~min}$. All the cultures were incubated in a culture room at $25 \pm 2{ }^{\circ} \mathrm{C}$ under a 16 -h photoperiod with a photosynthetic photon flux density of $60 \mu \mathrm{mol} \mathrm{m}{ }^{-2} \mathrm{~s}^{-1}$ supplied by Philips TL 40W fluorescent tubes. Each treatment consisted of 20 tubes with one explant each, and all experiments were repeated 3 times. The data were presented as mean values and their standard deviations (mean $\pm \mathrm{SD}$ ) and comparisons of mean values were carried out through Duncan's multiple range test (DMRT; Duncan 1995) at $0.05 \%$ significance.

\section{RESULTS AND DISCUSSION}

\section{Seed germination and cotyledonary node culture}

The seeds of $E$. scaber are comparatively small and dark brown in colour. The seeds were stored at $4{ }^{\circ} \mathrm{C}$ in a refrigerator. The seeds cultured in Petri plates lined with filter paper and soaked with MS medium showed initial signs of germination 3-4 days after culturing. The seeds increased in size and started germination one week after culturing. Fifty per cent of cultured seeds germinated after 
$30 \mathrm{~d}$ when fresh seeds were used (Figure 1A). However, the germination rate was low when stored seeds were used, suggesting a decrease in seed viability after storage (data not shown). The germinating seedlings showed well developed hypocotyls, radicals, and cotyledons after $15 \mathrm{~d}$ of culture. In the present study the cotyledonary node explants were isolated from the germinating seedlings at 15, 20, and 25 $\mathrm{d}$ of culturing.

The multiple shoot induction from cotyledonary node explants varied with the type and concentration of plant growth regulators, as well as seedling age (Table 1). The cotyledonary node explants failed to produce shoots on the MS basal medium. Incorporation of cytokinin into the medium was essential to induce multiple shoot proliferation from cotyledonary node explants. Explants obtained from 20-day-old seedlings (Figure 1B) produced a higher number of shoots, compared to those obtained from 15- or 25-day-old seedlings. Explant age plays a crucial role in multiple shoot induction from cotyledonary node explants, as evidenced by several previous reports for species, such as Morus alba (Thomas 2003) and Cassia sophera (Parveen and Shahzad 2010). Similar observations were also made for Asteraceae species like Eclipta alba (Baskaran and Jayabalan 2005) and Vernonia anthelmintica (Subhan and Agrawal 2011). The percentage of cultures responding and the mean number of shoots increased when the highest concentration of $2.0 \mathrm{mg}$ $\mathrm{L}^{-1} \mathrm{BA}$ was used. The optimum response $(66 \%)$ and number of shoots (12.3 per explant) was observed on the MS medium
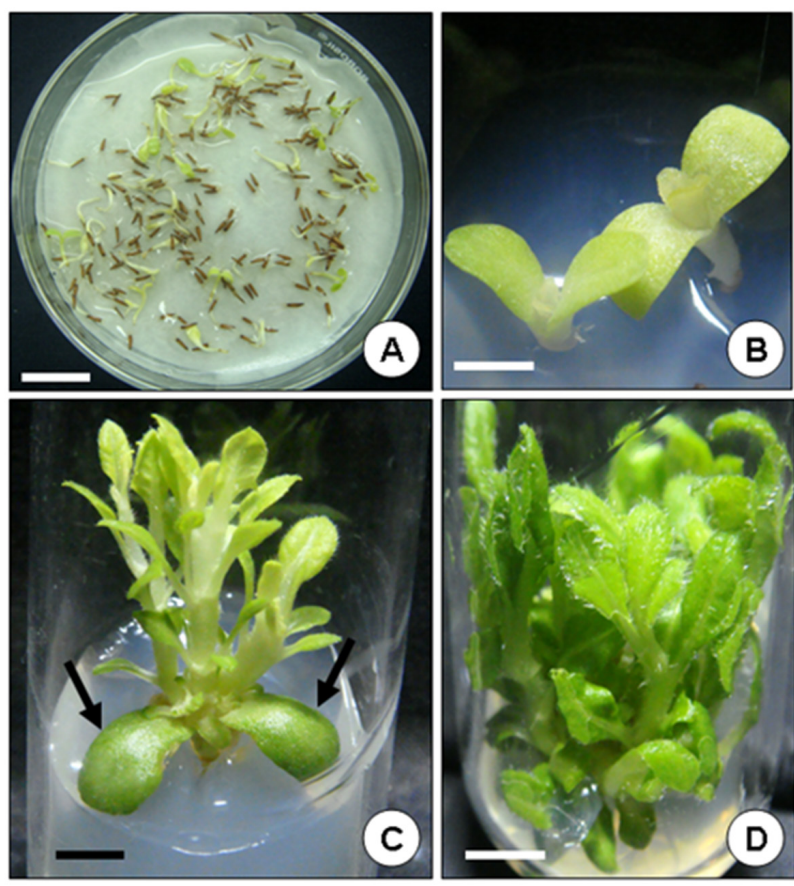

Figure 1. Various stages of shoot induction from cotyledonary node explants of E. scaber. A. In vitro seed germination on filter paper soaked in sterilized distilled water at $20 \mathrm{~d}$ of culturing. About $50 \%$ of the seeds germinated. $\mathrm{Bar}=3.0 \mathrm{~mm}$; B. The cotyledonary node just after culturing on MS medium supplemented with TDZ (1.5 $\left.\mathrm{mg} \mathrm{L}^{-1}\right)$ and NAA $(0.5 \mathrm{mg}$ $\left.\mathrm{L}^{-1}\right)$. Bar $=0.3 \mathrm{~cm} ; \mathrm{C}$. Multiple shoot induction from cotyledonary node explants 3 weeks after culturing on MS medium supplemented with TDZ $\left(1.5 \mathrm{mg} \mathrm{L}^{-1}\right)$ and NAA $\left(0.5 \mathrm{mg} \mathrm{L}^{-1}\right)$. Two cotyledons (arrows) are also visible. Bar $=0.6 \mathrm{~cm}$; D. Same as in Figure $2 \mathrm{C}, 30 \mathrm{~d}$ after culturing. More multiple shoots have emerged from the explants. $B a r=0.7 \mathrm{~cm}$

Table 1. Effect of various plant growth regulators on multiple shoot induction from 15, 20, and 25-day-old cotyledonary node explants of $E$. scaber. Medium: MS; Culture period: 45 days

\begin{tabular}{lccccccccccc}
\hline \multicolumn{1}{l}{ Plant growth regulators $\left(\mathrm{mg} \mathrm{L}^{-1}\right)$} & \multicolumn{3}{c}{ \% response } & \multicolumn{3}{c}{ Mean no. of shoots* } \\
\hline BA & TDZ & NAA & $15 \mathrm{~d}$ & $20 \mathrm{~d}$ & $25 \mathrm{~d}$ & $15 \mathrm{~d}$ & $20 \mathrm{~d}$ & $25 \mathrm{~d}$ & $15 \mathrm{~d}$ & $20 \mathrm{~d}$ \\
0.0 & 0.0 & 0.0 & $0.0 \mathrm{f}$ & $0.0 \mathrm{~g}$ & $0.0 \mathrm{~g}$ & $0.0 \mathrm{~g}$ & $0.0 \mathrm{~g}$ & $0.0 \mathrm{~h}$ & $0.0 \mathrm{~b}$ & $0.0 \mathrm{~b}$ & $0.0 \mathrm{~b}$ \\
0.5 & - & & $45 \mathrm{e}$ & $52 \mathrm{f}$ & $49 \mathrm{f}$ & $2.0 \pm 0.6 \mathrm{f}$ & $2.3 \pm 0.6 \mathrm{f}$ & $2.1 \pm 0.8 \mathrm{~g}$ & $0.6 \pm 0.2 \mathrm{a}$ & $0.7 \pm 0.3 \mathrm{a}$ & $0.5 \pm 0.3 \mathrm{a}$ \\
1.0 & - & & $48 \mathrm{~d}$ & $58 \mathrm{f}$ & $52 \mathrm{e}$ & $5.6 \pm 1.7 \mathrm{e}$ & $7.8 \pm 2.1 \mathrm{e}$ & $4.8 \pm 1.4 \mathrm{f}$ & $0.7 \pm 0.3 \mathrm{a}$ & $0.7 \pm 0.4 \mathrm{a}$ & $0.8 \pm 0.4 \mathrm{a}$ \\
1.5 & - & & $51 \mathrm{~d}$ & $61 \mathrm{e}$ & $57 \mathrm{e}$ & $6.2 \pm 1.2 \mathrm{~d}$ & $8.3 \pm 2.3 \mathrm{~d}$ & $5.3 \pm 1.9 \mathrm{e}$ & $0.8 \pm 0.2 \mathrm{a}$ & $0.8 \pm 0.3 \mathrm{a}$ & $0.9 \pm 0.2 \mathrm{a}$ \\
2.0 & - & & $54 \mathrm{~d}$ & $66 \mathrm{~d}$ & $61 \mathrm{~d}$ & $8.1 \pm 2.1 \mathrm{~d}$ & $12.3 \pm 1.8 \mathrm{~d}$ & $6.6 \pm 1.8 \mathrm{e}$ & $0.6 \pm 0.3 \mathrm{a}$ & $0.7 \pm 0.4 \mathrm{a}$ & $0.8 \pm 0.3 \mathrm{a}$ \\
3.0 & - & & $51 \mathrm{~d}$ & $63 \mathrm{e}$ & $58 \mathrm{~d}$ & $5.3 \pm 1.0 \mathrm{e}$ & $8.4 \pm 2.3 \mathrm{~d}$ & $5.5 \pm 1.4 \mathrm{e}$ & $0.8 \pm 0.3 \mathrm{a}$ & $0.8 \pm 0.3 \mathrm{a}$ & $0.7 \pm 0.4 \mathrm{a}$ \\
- & 0.5 & & $52 \mathrm{~d}$ & $64 \mathrm{~d}$ & $57 \mathrm{e}$ & $6.9 \pm 1.3 \mathrm{~d}$ & $8.3 \pm 1.9 \mathrm{~d}$ & $5.9 \pm 2.3 \mathrm{e}$ & $0.6 \pm 0.2 \mathrm{a}$ & $0.9 \pm 0.2 \mathrm{a}$ & $0.7 \pm 0.3 \mathrm{a}$ \\
- & 1.0 & & $56 \mathrm{~d}$ & $68 \mathrm{~d}$ & $59 \mathrm{~d}$ & $8.3 \pm 2.4 \mathrm{~d}$ & $9.3 \pm 2.8 \mathrm{~d}$ & $6.8 \pm 1.9 \mathrm{~d}$ & $0.9 \pm 0.3 \mathrm{a}$ & $0.8 \pm 0.4 \mathrm{a}$ & $0.8 \pm 0.4 \mathrm{a}$ \\
- & 1.5 & & $59 \mathrm{~d}$ & $71 \mathrm{c}$ & $68 \mathrm{~d}$ & $10.3 \pm 2.6 \mathrm{c}$ & $16.3 \pm 2.7 \mathrm{c}$ & $8.8 \pm 2.3 \mathrm{c}$ & $0.8 \pm 0.2 \mathrm{a}$ & $0.8 \pm 0.3 \mathrm{a}$ & $0.8 \pm 0.2 \mathrm{a}$ \\
- & 2.0 & & $55 \mathrm{~d}$ & $65 \mathrm{~d}$ & $64 \mathrm{~d}$ & $8.9 \pm 1.9 \mathrm{~d}$ & $9.6 \pm 2.5 \mathrm{~d}$ & $8.1 \pm 2.4 \mathrm{c}$ & $0.8 \pm 0.3 \mathrm{a}$ & $0.6 \pm 0.3 \mathrm{a}$ & $0.9 \pm 0.3 \mathrm{a}$ \\
- & 3.0 & & $54 \mathrm{~d}$ & $66 \mathrm{~d}$ & $62 \mathrm{~d}$ & $7.7 \pm 1.2 \mathrm{~d}$ & $9.1 \pm 2.1 \mathrm{~d}$ & $7.8 \pm 2.7 \mathrm{~d}$ & $0.7 \pm 0.3 \mathrm{a}$ & $0.6 \pm 0.4 \mathrm{a}$ & $0.9 \pm 0.4 \mathrm{a}$ \\
2.0 & - & 0.3 & $59 \mathrm{~d}$ & $61 \mathrm{e}$ & $64 \mathrm{~d}$ & $10.3 \pm 1.8 \mathrm{c}$ & $16.7 \pm 2.8 \mathrm{c}$ & $9.8 \pm 2.8 \mathrm{c}$ & $0.6 \pm 0.4 \mathrm{a}$ & $0.7 \pm 0.2 \mathrm{a}$ & $0.8 \pm 0.3 \mathrm{a}$ \\
2.0 & - & 0.5 & $61 \mathrm{c}$ & $67 \mathrm{~d}$ & $68 \mathrm{~d}$ & $12.7 \pm 2.1 \mathrm{c}$ & $19.2 \pm 2.7 \mathrm{c}$ & $14.8 \pm 3.4 \mathrm{~b}$ & $0.8 \pm 0.3 \mathrm{a}$ & $0.7 \pm 0.3 \mathrm{a}$ & $0.8 \pm 0.4 \mathrm{a}$ \\
2.0 & - & 1.0 & $66 \mathrm{c}$ & $79 \mathrm{c}$ & $76 \mathrm{c}$ & $16.4 \pm 3.3 \mathrm{~b}$ & $22.7 \pm 3.2 \mathrm{~b}$ & $16.2 \pm 3.6 \mathrm{~b}$ & $0.8 \pm 0.4 \mathrm{a}$ & $0.8 \pm 0.4 \mathrm{a}$ & $0.9 \pm 0.3 \mathrm{a}$ \\
& 1.5 & 0.3 & $71 \mathrm{~b}$ & $83 \mathrm{~b}$ & $80 \mathrm{~b}$ & $15.3 \pm 3.1 \mathrm{~b}$ & $27.6 \pm 4.5 \mathrm{~b}$ & $11.5 \pm 3.2 \mathrm{~b}$ & $0.9 \pm 0.3 \mathrm{a}$ & $0.9 \pm 0.4 \mathrm{a}$ & $0.8 \pm 0.3 \mathrm{a}$ \\
& 1.5 & 0.5 & $78 \mathrm{a}$ & $98 \mathrm{a}$ & $91 \mathrm{a}$ & $18.4 \pm 4.7 \mathrm{a}$ & $33.7 \pm 6.2 \mathrm{a}$ & $22.6 \pm 5.3 \mathrm{a}$ & $0.9 \pm 0.3 \mathrm{a}$ & $0.9 \pm 0.3 \mathrm{a}$ & $0.9 \pm 0.4 \mathrm{a}$ \\
& 1.5 & 1.0 & $73 \mathrm{~b}$ & $91 \mathrm{~b}$ & $85 \mathrm{~b}$ & $14.6 \pm 3.2 \mathrm{~b}$ & $25.2 \pm 4.2 \mathrm{~b}$ & $10.8 \pm 4.8 \mathrm{~b}$ & $0.7 \pm 0.4 \mathrm{a}$ & $0.8 \pm 0.2 \mathrm{a}$ & $0.8 \pm 0.2 \mathrm{a}$ \\
\hline
\end{tabular}

${ }^{*}$ The values represent the means $( \pm \mathrm{SE})$ of three independent experiments. At least 20 cultures were raised for each experiment.

Mean values within a column followed by the same letter are not significantly different by Duncan's multiple range test $(\mathrm{P} \geq 0.05)$ 
supplemented with $2.0 \mathrm{mg} \mathrm{L}^{-1} \mathrm{BA}$. The BA concentration beyond $2.0 \mathrm{mg} \mathrm{L}^{-1}$ did not enhance shoot production; rather, there was a decline in the number of shoots. Among the various concentrations of TDZ used, $1.5 \mathrm{mg} \mathrm{L}^{-1} \mathrm{TDZ}$ gave the optimum response (71\%) and number of shoots $(16.3$ shoots per explant) when 20-day-old seedlings were cultured (Table 1). Simultaneous addition of NAA (0.3-1.0 $\left.\mathrm{mg} \mathrm{L}^{-1}\right)$ and a cytokinin significantly improved the shoot induction efficiency of cotyledonary node explants. The cotyledonary node explants started to enlarge and produce direct multiple shoots within 2-3 wk after culturing (Figure 1C). Within one month, several multiple shoots with many leaves had emerged from the cotyledonary node (Figure 1D). There was no callus formation from the explants. Ninety eight per cent of the cultures produced multiple shoots with an average of 33.7 shoots per explant when 20 -day-old cotyledonary node explants were cultured on MS medium supplemented with $1.5 \mathrm{mg} / \mathrm{l} \mathrm{TDZ}$ and $0.5 \mathrm{mg} \mathrm{L}^{-1}$ NAA after $45 \mathrm{~d}$ of culture (Figure 2A; Table 1). The superiority of TDZ, a substituted phenyl urea, over other adenine type cytokinins for shoot induction in cultures has been well documented in several systems (Cheruvathur et al. 2013, Cordeiro et al. 2014). In the present study, a combination of TDZ and NAA produced the highest response. Synergistic effect of TDZ and NAA on shoot induction has been reported in several plant systems, such as Gentiana kurroo (Sharma et al. 2014) and Artemesia vulgaris (Sujatha and Kumari 2007).

\section{Shoot elongation rooting and field transfer}

Although a large number of shoots was formed from the cotyledonary node explants on various media, the mean shoot length was low. The average shoot length ranged from 0.5-0.9 $\mathrm{cm}$ on various shoot induction media (Table 1). Therefore, each shoot was excised from the multiple shoot clusters and cultured on MS medium supplemented with $0.5 \mathrm{mg} \mathrm{L}^{-1} \mathrm{BA}$ for shoot elongation. On this medium, the shoots showed rapid growth and reached an average length of $3.5 \mathrm{~cm}$ after $30 \mathrm{~d}$ of culturing (Figure 2B).

Shoots of 3.5-4.0 cm were transferred to half-strength MS medium supplemented with various concentrations of NAA $\left(0.5-2.0 \mathrm{mg} \mathrm{L}^{-1}\right)$, IBA $\left(0.5-2.0 \mathrm{mg} \mathrm{L}^{-1}\right)$, or IAA (0.5-2.0 $\left.\mathrm{mg} \mathrm{L}^{-1}\right)$ for root induction. No root formation was observed when shoots were cultured on MS basal medium. Although root induction was observed on all auxins tested, IBA was comparatively better than other auxins (Table 2). The highest root induction $(\mathrm{P} \geq 0.05)$ was observed on halfstrength MS medium supplemented with $1.0 \mathrm{mg} \mathrm{L}^{-1}$ IBA. At this concentration, $100 \%$ of the shoots rooted, with an average number of 3.2 roots per shoot (Table 2; Figure 2C). The use of half-strength MS medium for root induction has
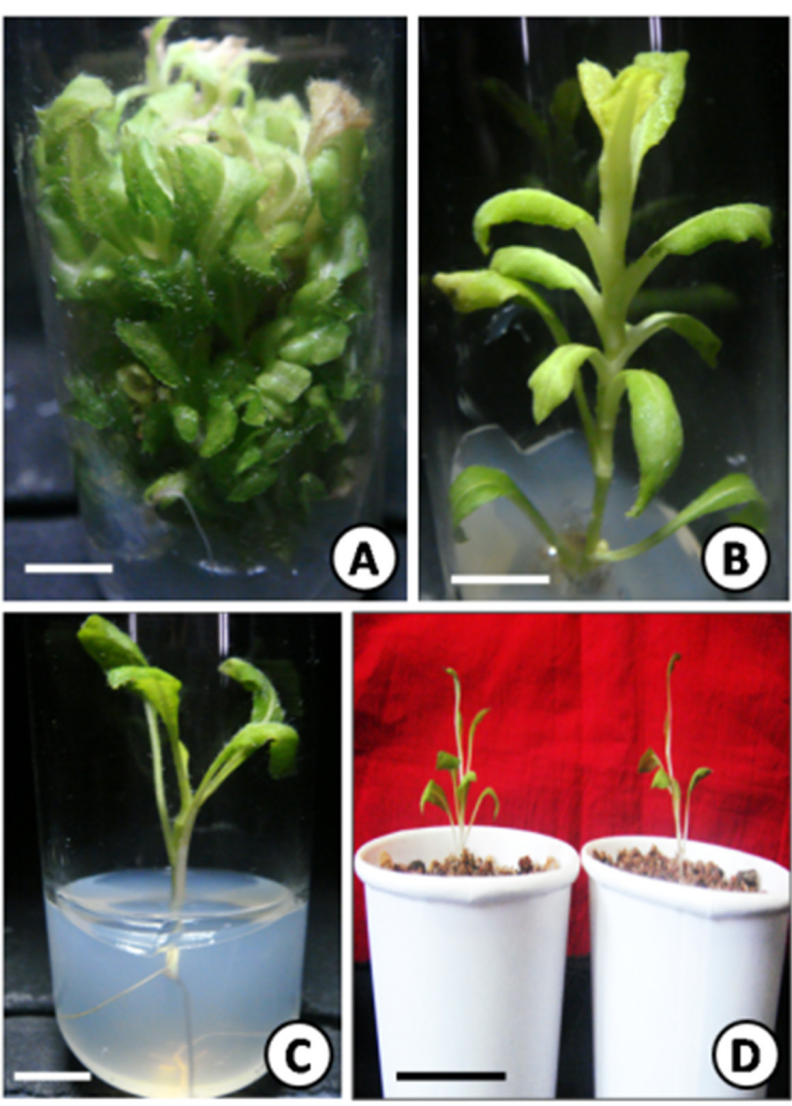

Figure 2. Multiple shoot induction, shoot elongation, rooting, and transplantation of plants in E. scaber. A. Multiple shoots induced $45 \mathrm{~d}$ after culturing on MS medium, augmented with TDZ $\left(1.5 \mathrm{mg} \mathrm{L}^{-1}\right)$ and NAA $\left(0.5 \mathrm{mg} \mathrm{L}^{-1}\right)$. A large number of shoots were formed. Bar $=0.7 \mathrm{~cm}$; B. Elongation of shoots on MS medium supplemented with $0.5 \mathrm{mg} / 1 \mathrm{BA}$. The shoots reach an average size of about $3.5 \mathrm{~cm}$ in $30 \mathrm{~d}$. Bar $=1.2 \mathrm{~cm}$; C. Rooting of shoots on half-strength MS medium supplemented with $1.0 \mathrm{mg} \mathrm{L}^{-1}$ IBA after $45 \mathrm{~d}$. Whitish roots have emerged from the basal cut end of the shoot. Bar $=1.0 \mathrm{~cm}$; D. Two transplanted plants in expanded polystyrene cups 2 months after transfer. $\mathrm{Bar}=3.0 \mathrm{~cm}$

been reported in several systems, including Rhinacanthus nasutus (Cheruvathur and Thomas 2014) and Caesalpinia bonduc (Cheruvathur et al. 2012). In the present study, the addition of IBA to the medium produced a higher response than the other auxins. This observation is in agreement with other systems, where IBA induced optimum rooting (Beena et al. 2003)

The rooted shoots were transferred to expanded polystyrene cups containing autoclaved garden soil and sand $(1: 1 \mathrm{v} / \mathrm{v})$ and placed in a greenhouse under high humidity. The plants were watered every day and were transferred to shade after two months (Figure 2D). Of the 66 plants transferred to soil, 61 survived.

In conclusion, the protocol described here provides an efficient method for the rapid multiplication of E. scaber. 
Table 2. Effect of various auxins on rooting of shoots on half-strength MS medium after $45 \mathrm{~d}$ of culture

\begin{tabular}{lccccc}
\hline $\begin{array}{l}\text { Auxins }\left(\mathrm{mg} \mathrm{L}^{-1}\right) \\
\text { NAA }\end{array}$ & IBA & IAA & \% shoots rooted & Mean no. of roots* & Mean root length $(\mathrm{cm}) *$ \\
\hline 0.0 & 0.0 & 0.0 & $0.0 \mathrm{~g}$ & $0.0 \mathrm{~d}$ & $0.0 \mathrm{~b}$ \\
0.5 & - & - & $45 \mathrm{f}$ & $1.4 \pm 0.3 \mathrm{c}$ & $3.1 \pm 0.3 \mathrm{a}$ \\
1.0 & - & - & $68 \mathrm{~d}$ & $1.7 \pm 0.2 \mathrm{~b}$ & $3.3 \pm 0.4 \mathrm{a}$ \\
1.5 & - & - & $71 \mathrm{c}$ & $2.4 \pm 0.4 \mathrm{~b}$ & $3.6 \pm 0.6 \mathrm{a}$ \\
2.0 & - & - & $66 \mathrm{~d}$ & $1.9 \pm 0.4 \mathrm{~b}$ & $3.0 \pm 0.7 \mathrm{a}$ \\
- & 0.5 & - & $78 \mathrm{c}$ & $1.9 \pm 0.5 \mathrm{~b}$ & $3.2 \pm 0.6 \mathrm{a}$ \\
- & 1.0 & - & $100 \mathrm{a}$ & $3.2 \pm 0.3 \mathrm{a}$ & $3.4 \pm 0.5 \mathrm{a}$ \\
- & 1.5 & - & $90 \mathrm{~b}$ & $2.1 \pm 0.5 \mathrm{~b}$ & $3.3 \pm 0.8 \mathrm{a}$ \\
- & 2.0 & - & $65 \mathrm{~d}$ & $1.8 \pm 0.6 \mathrm{~b}$ & $3.5 \pm 0.5 \mathrm{a}$ \\
- & - & 0.5 & $55 \mathrm{e}$ & $1.7 \pm 0.5 \mathrm{~b}$ & $3.1 \pm 0.4 \mathrm{a}$ \\
- & - & 1.0 & $67 \mathrm{~d}$ & $1.9 \pm 0.4 \mathrm{~b}$ & $2.9 \pm 0.8 \mathrm{a}$ \\
- & - & 1.5 & $78 \mathrm{c}$ & $2.1 \pm 0.5 \mathrm{~b}$ & $3.8 \pm 0.6 \mathrm{a}$ \\
\hline
\end{tabular}

"The values represent the means $( \pm \mathrm{SE})$ of three independent experiments. At least 20 cultures were raised for each experiment

Mean values within a column followed by the same letter are not significantly different by Duncan's multiple range test (P $\geq 0.05)$

Cotyledonary node explants from 20-day-old seedlings may be used to obtain high frequency direct shoot regeneration. A combination of $1.5 \mathrm{mg} \mathrm{L}^{-1} \mathrm{TDZ}$ and $0.5 \mathrm{mg} \mathrm{L}^{-1} \mathrm{NAA}$ produced the best shoot induction from cotyledonary node explants. This protocol also has the advantage of establishing long-term cultures with a high multiplication coefficient. In addition to being used for extraction of bioactive compounds to reduce pressure on wild stocks, the regenerated plantlets could be used to replenish declining populations in the wild, making a valuable contribution to preservation of the species. Thus, the method of multiplication reported here shows great potential for recovering the species, for propagation and conservation, production of useful phytochemicals, and genetic manipulation of this valuable medicinal plant.

\section{ACKNOWLEDGEMENTS}

We thank the Principal of St. Thomas College, Palai for providing necessary facilities.

\section{Sistema eficiente de regeneração de brotos para a espécie medicinal Elephantopus scaber Linn.}

Resumo - Um protocolo eficiente para a rápida micropropagação da planta medicinalmente importante Elephantopus scaber foi padronizado a partir de explantes de nós cotiledonares. Indução de brotações múltiplas diretas foi observada quando os explantes de vários idades foram cultivadas em meio MS suplementado com vários reguladores de crescimento. A maior indução de brotos foi obtida quando os explantes de mudas de 20 dias foram cultivadas em meio MS suplementado com 1,5 mg $L^{-1}$ TDZ e 0,5 mg L $L^{-1}$ NAA. Neste meio, $98 \%$ dos cultivos responderam, com um número médio de 33,7 brotos por explante. A maior frequência de enraizamento (100\%) e número médio de raizes (3,3 por broto) foram observados quando os brotos foram transferidos para meio MS suplementado com 1,0 $\mathrm{mg} \mathrm{L}^{-1}$ de IBA. As mudas cultivadas in vitro foram aclimatizadas e transferidas para solo com sucesso de $92 \%$. Este protocolo pode ser utilizado para a multiplicação e conservação de clones elite de E. scaber.

Palavras-chave: Aclimatação, nó cotiledonar, Elephantopus scaber, brotos múltiplos, enraizamento.

\section{REFERENCES}

Baskaran P and Jayabalan N (2005) An efficient micropropagation system for Eclipta alba- a valuable medicinal herb. In Vitro Cellular and Developmental Biology - Plant 41: 532-539.

Beena MR, Martin KP, Kirti PB and Hariharan M (2003) Rapid in vitro propagation of medicinally important Ceropegia candelabrum. Plant Cell Tissue and Organ Culture 72: 285-289.

Behera SK and Misra MK (2005) Indigenous phytotherapy for genitorurinary diseases used by the Kandha tribe of Orissa. Journal of Ethnopharmacology 102: 319-325.
Cabrera AL and Klein RM (1980) Flora Ilustruda Cafarinense. Compositae. 3. Tribo: Vernoniae, VI. Genero Elephantopus, p. 397-402.

Chang CL, Shen CC, Ni CL and Chen CC (2011) A new sesquiterpene from Elephantopus scaber. Hung Kuang Journal 65: 49-56.

Cheruvathur MK, Britto J and Thomas TD (2012) Pulvinus: an ideal explant for plant regeneration in Caesalpinia bonduc (L.) Roxb., an important ethnomedicinal woody climber. Acta Physiologiae Plantarum 34: 693-699.

Cheruvathur MK, Abraham J and Thomas TD (2013) Plant regeneration 
through callus organogenesis and true-to-type conformity of plants by RAPD analysis in Desmodium gangeticum (Linn.) DC. Applied Biochemistry and Biotechnology 169: 1799-1810.

Cheruvathur MK and Thomas TD (2014) Shoot organogenesis from rootderived callus of Rhinacanthus nasutus (L.) Kurz. and assessment of clonal fidelity of micropropagated plants using RAPD analysis. Applied Biochemistry and Biotechnology 172: 1172-1182.

Cordeiro SZ, Simas NK, Henriques AB and Sato A(2014) Micropropagation and callogenesis in Mandevilla guanabarica (Apocynaceae), an endemic plant from Brazil. Crop Breeding and Applied Biotechnology 14: 108-115.

Corral P, Mallón R, Rodríguez-Oubiña J, Luz González M (2011) Multiple shoot induction and plant regeneration of the endangered species Crepis novoana. Plant Cell Tissue and Organ Culture 105: 211-217.

Duncan DB (1995) Multiple range and multiple F tests. Biometrics 11: $1-42$.

Geetha BS, Nair MS, Latha PG and Remani P (2012) Sesquiterpene lactones isolated from Elephantopus scaber L. inhibits human lymphocyte proliferation and the growth of tumour cell lines and induces apoptosis in vitro. Journal of Biomedicine and Biotechnology 2012: 1-8.

Hammer MLA and Johns EA (1993) Tapping an Amazonian plethora: four medicinal plants of Marajo Island, Para (Brazil). Journal of Ethnopharmacology 40: 53-75.

Hiradeve SM and Rangari VD (2014) Elephantopus scaber Linn.: A review on its ethnomedical, phytochemical and pharmacological profile. Journal of Applied Biomedicine 12: 49-61.

Jagadeesh Singh SD, Krishna V, Vidya SM, Manjunath BK, Mankani KL and Shankarmurthy K (2004) Micropropagation of Elephantopus scaber through leaf segments. Journal of Tropical Medicinal Plants 5: $245-248$.

Kiritikar KD and Basu BD (1991) Indian Medicinal Plants. 2nd edn, International Book Distributors, Deharadun, p. 1328-1329.

Lee WL and Shyur LF (2012) Deoxyelephantopin impedes mammary adenocarcinoma cell motility by inhibiting calpain-mediated adhesion dynamics and inducing reactive oxygen species and aggresome formation. Free Radical Biology and Medicine 52: 1423-1436.

Murashige T and Skoog F (1962) A revised medium for rapid growth and bioassays with tobacco tissue cultures. Physiolgiae Plantarum 15: 473-497.

Parashurama TR, Vasanthakumari MM and Shivanna MB (2013) Colletotrichum disease of Elephantopus scaber and its effect on secondary metabolites. International Journal of Pharmaceutical and Bioscience 4: 871-883.

Parveen S and Shahzad A (2010) TDZ-induced high frequency shoot regeneration in Cassia sophera Linn. via cotyledonary node explants. Physiology and Molecular Biology of Plants 16: 201-206.

Rajakumar N and Shivanna MB (2010) Traditional herbal medicinal knowledge in Sagar taluk of Shimoga district, Karnataka, India. Indian Journal of Natural Product Resources 1: 102-108.

Rodrigues LA, Paiva Neto VB, Boaretto AG, Oliveira JF, Torrezan MA, Lima SF and Otoni WC (2015) In vitro propagation of Cyrtopodium saintlegerianum rchb. f. (orchidaceae), a native orchid of the Brazilian savannah. Crop Breeding and Applied Biotechnology 15: 10-17.

Rout JR and Sahoo SL (2013) In vitro propagation and antioxidant enzymes activities of Elephantopus scaber L. Asia Pacific Journal of Molecular Biology and Biotechnology 21: 59-66.

Sharma A, Kaur R and Sharma N (2014) In vitro morphogenic response of different explants of Gentiana kurroo Royle from Western Himalayas - an endangered medicinal plant. Physiology and Molecular Biology of Plants 20: 249-256.

Subhan S and Agrawal V (2011) Efficient in vitro propagation of purple fleabane (Vernonia anthelmintica wild.): a multipurpose under exploited oil- yielding herb. International Journal of Pharmacy and Biosciences 2: B231-B241.

Sujatha G and Kumari BD (2007) Effect of phytohormones on micro propagation of Artemisia vulgaris L. Acta Physiologiae Plantarum 29: 189-195.

Thomas TD (2003) Thidiazuron induced multiple shoot induction and plant regeneration from cotyledonary explants of mulberry. Biologia Plantarum 46: 529-533. 